\title{
PENGGUNAAN PRODUK FERMENTASI DAN KUNYIT DALAM PAKAN TERHADAP PERFORMAN AYAM PEDAGING DAN INCOME OVER FEED AND CHICK COST
}

\author{
Nurhayati, Chandra Utami Wirawati, dan Dwi Desmiyeni Putri \\ Politeknik Negeri Lampung, Jl. Soekarno-Hatta No.10, Rajabasa Bandar Lampung \\ Email: nurhayati.dakhlan@gmail.com
}

\begin{abstract}
ABSTRAK
Penelitian ini bertujuan untuk mengetahui tingkat penggunaan produk fermentasi campuran bungkil inti sawit dan onggok yang dikombinasi dengan kunyit dalam pakan terhadap performan ayam pedaging, dan income over feed and chick cost (IOFCC). Penelitian dirancang menggunakan Rancangan Acak Lengkap pola faktorial $4 \times 2 \times 2$, faktor pertama tingkat penggunaan produk fermentasi dalam pakan $(0,10,20$, dan $30 \%$ ), faktor kedua pemberian kunyit (tanpa dan diberi kunyit 2,5\% dari total pakan), dan faktor ketiga perlakuan vaksin (tanpa divaksin dan dengan divaksin). Peubah yang diamati meliputi konsumsi pakan dan air minum, konversi pakan, pertambahan bobot badan, dan IOFCC. Hasil penelitian menunjukkan tidak ada interaksi antara tingkat penggunaan produk fermentasi, penambahan kunyit, dan perlakuan vaksin terhadap performan ayam pedaging. Hasil penelitian juga menunjukkan bahwa penambahan produk fermentasi sebanyak $10 \%$ dalam pakan ayam pedaging dapat meningkatkan performan ayam pedaging (PBB dan konversi pakan). Penambahan produk fermentasi $10 \%$ dan penambahan kunyit 2,5\% dalam pakan dapat menghasilkan IOFCC yang lebih tinggi dibandingkan dengan kontrol. Penambahan produk fermentasi, penambahan kunyit dalam pakan, dan perlakuan pemberian vaksin tidak mempengaruhi konsumsi pakan, dan konsumsi air minum.
\end{abstract}

Kata kunci: Produk fermentasi, kunyit, performan ayam pedaging, IOFCC

\section{ABSTRACT}

THE UTILIZATION OF
FERMENTATION PRODUCT AND
CURCUMA IN RATION ON BROILER
PERFORMANCE, AND INCOME OVER
FEED AND CHICK COST. The aim of this
study was to investigate the utilization level of fermentation product combined with curcuma in ration on broiler performace, and income over feed and chick cost (IOFCC). Completely Randomized Design with $4 \times 2 \times 2$ factorial arrangement was used in this research. The first factor were levels of fermentation product in ration $(0,10,20$, dan $30 \%)$, the second factor were curcuma addition in ration $(0 \%$ and $2,5 \%$ ), and the third factor were vaccine applications (without and with vaccine application). The results showed that there were no interaction among the utilization levels of fermentation product, the addition of curcuma, and vaccine applications on broiler performance. The results also indicated that $10 \%$ utilization of fermentation product in broiler ration could increase broiler performance (weight gain and feed conversion). $10 \%$ utilization of Fermentation product and addition of $2.5 \%$ curcuma in ration could produce higher IOFCC compared to control diet. Utilization of fermentation product, curcuma addition in ration, and vaccine application did not affect ration and water consumption.

Key words: fermentation product, curcuma, broiler performance, IOFCC. 


\section{PENDAHULUAN}

Semakin tingginya harga pakan konvensional seperti jagung dan konsentrat menuntut peternak ayam pedaging untuk mencari bahan pakan alternatif yang murah tapi berkualitas tinggi yang menyamai atau melebihi pakan konvensional. Bungkil inti sawit dan onggok merupakan limbah pertanian yang sangat murah namun bisa ditingkatkan kualitas nutrisinya melalui teknologi fermentasi. Nurhayati dkk (2006 dan 2011) melaporkan bahwa campuran bungkil inti sawit dan onggok yang difermentasi dapat meningkat nilai nutrisinya. Disamping itu produk fermentasi mengandung probiotik yang bermanfaat menjaga keseimbangan komposisi mikroorganisme dalam sistem pencernaan unggas dan menekan mikroorganisme patogen sehingga meningkatkan daya cerna bahan pakan, menjaga kesehatan serta meningkatkan kekebalan tubuh.

Hasil penelitian Nurhayati (2007) menunjukkan bahwa tingkat penggunaan campuran bungkil inti sawit dan onggok terfermentasi dalam pakan mempengaruhi $(\mathrm{P}<0,06)$ konsumsi pakan, $\mathrm{PBB}$, dan Income Over Feed and Chick Cost tetapi tidak mempengaruhi $(\mathrm{P}>0,06)$ konversi pakan. Penggunaan campuran bungkil inti sawit dan onggok terfermentasi dalam pakan sampai 30 persen masih lebih baik dibandingkan dengan kontrol.

Penggunaan kunyit dalam pakan unggas berfungsi meningkatkan kerja organ pencernaan unggas yaitu merangsang dinding kantong empedu mengeluarkan cairan empedu dan merangsang keluarnya getah pankreas yang mengandung enzim amilasi, lipase, dan protease sehingga meningkatkan pencernaan bahan pakan seperti karbohidrat, lemak dan protein. Minyak atsiri yang terkandung dalam kunyit dapat mempercepat pengosongan isi lambung sehingga meningkatkan konsumsi pakan dan PBB. Selain itu kunyit mengandung kurkumin yang mempunyai kegunaan sebagai antioksidan dan meningkatkan kekebalan tubuh sehingga penggunaan beberapa vaksin sebagai upaya meningkatkan kekebalan tubuh ternak dapat digantikan oleh keberadaan kunyit.

Penggunaan kunyit dalam ransum broiler telah diteliti oleh peneliti sebelumnya. Hasil penelitian Tantalo (2006) menunjukkan bahwa penambahan kunyit dalam air minum sebanyak 10-20 g/l dengan menggunakan berbagai ransum komersial bervariasi dapat meningkatkan $(\mathrm{P}<0.01)$ konsumsi ransum, pertambahan bobot tubuh, bobot karkas, dan konversi ransum. Hasil penelitian Retnaningati dan Tutik (2006) menunjukkan bahwa 
penambahan bahan herbal (jahe, temulawak, dan kunyit) sebanyak 2,5\% dari pakan komersial berpengaruh nyata terhadap konsumsi pakan, pertambahan berat badan dan konversi pakan. Namun demikian, hasil penelitian Nova (2001) menunjukkan bahwa penggunaan tepung kunyit sampai $1,2 \%$ dalam ransum tidak memberikan pengaruh yang signifikan terhadap konsumsi pakan dan pertambahan bobot tubuh, tetapi sangat nyata $(\mathrm{P}<0.01)$ mempengaruhi efisiensi pakan.

Berdasarkan uraian diatas perlu dikaji lebih lanjut sejauh mana pengaruh produk fermentasi yang mengandung probiotik yang dikombinasi dengan kunyit dapat meningkatkan efisiensi pencernaan pakan dan performans unggas dan akhirnya terhadap keuntungan (IOFCC). Oleh karena itu, penelitian ini diarahkan untuk mengetahui pengaruh level produk fermentasi yang disinergiskan dengan penambahan kunyit dalam pakan untuk meningkatkan performan ayam pedaging dan IOFCC.

\section{MATERI DAN METODE PENELITIAN}

\section{Bahan percobaan}

Percobaan lapang ini dilakukan di Kandang Ternak Politeknik negeri Lampung. Bahan yang digunakan adalah
DOC ayam pedaging sebanyak 288 ekor strain $\mathrm{CP}$ 707, produk fermentasi campuran bungkil inti sawit dan onggok, konsentrat, jagung, dan bekatul, kunyit, vaksin, dan obat-obatan. Susunan pakan percobaan disajikan pada Tabel 1 dan Tabel 2.

\section{Alat percobaan}

Alat yang digunakan adalah kandang litter, seperangkat alat pakan dan minum, timbangan digital kapasitas $210 \mathrm{~g}$ dengan ketelitian 0,001g, timbangan kue kapasitas 2 kg dengan ketelitian 0.1g, timbangan digital kapasitas $5 \mathrm{~kg}$ dengan ketelitian 0,001g, lampu penerang, termometer, higrometer, alat pembersih kandang, dan oven, serta kayu reng dan kasa plastik untuk penyekat petak.

DOC pada percobaan aplikasi produk fermentasi ini dipelihara dalam kandang litter yang disekat sesuai dengan kebutuhan dengan ukuran 1x1,5 m2 untuk setiap petak sebanyak 48 petak. Pada awalnya DOC ditimbang dan dialokasi ke 48 unit kandang percobaan dengan masing-masing unit terdiri dari 6 ekor ayam pedaging. Selanjutnya $4 \times 2 \times 2$ perlakuan dengan 3 ulangan secara acak dikenakan ke 48 unit percobaan. Kelompok ayam perlakuan terdiri dari perlakuan tingkat penggunaan produk fermentasi $(\mathrm{P} 0=0 \%, \mathrm{P} 1=10 \%, \mathrm{P} 2=$ $20 \%$, dan $\mathrm{P} 3=30 \%$ dari total pakan), 
Tabel 1. Susunan pakan percobaan ayam pedaging periode starter dan finisher

\begin{tabular}{|c|c|c|c|c|}
\hline \multirow{2}{*}{ Bahan pakan } & \multicolumn{4}{|c|}{ Pakan perlakuan starter(\%) } \\
\hline & P0 & P1 & P2 & P3 \\
\hline Pakan konsentrat $^{1)}$ & 46 & 40 & 34 & 28 \\
\hline Jagung $^{2)}$ & 54 & 50 & 46 & 42 \\
\hline Produk fermentasi ${ }^{3)}$ & 0 & 10 & 20 & 30 \\
\hline Total & 100 & 100 & 100 & 100 \\
\hline \multirow{2}{*}{ Bahan pakan } & \multicolumn{4}{|c|}{ Pakan perlakuan finisher $(\%)$} \\
\hline & P0 & $\mathrm{P} 1$ & $\mathrm{P} 2$ & P3 \\
\hline Pakan konsentrat $^{1)}$ & 36 & 30 & 24 & 18 \\
\hline Jagung $^{2)}$ & 51,5 & 47,5 & 43,5 & 39,5 \\
\hline Bekatul $^{2)}$ & 10 & 10 & 10 & 10 \\
\hline Produk fermentasi ${ }^{3)}$ & 0 & 10 & 20 & 30 \\
\hline Minyak $^{2)}$ & 2,5 & 2,5 & 2,5 & 2,5 \\
\hline Total & 100 & 100 & 100 & 100 \\
\hline
\end{tabular}

Keterangan: ${ }^{1)}$ Berdasarkan analisis kandungan zat makanan pabrik Confeed, ${ }^{2)}$ Berdasarkan tabel kandungan zat makanan (Wahyu, 1992),

${ }^{3)}$ Berdasarkan hasil penelitian Nurhayati (2011),

Tabel 2. Kandungan zat makanan periode starter dan finisher pada masing-masing perlakuan

\begin{tabular}{ccccc}
\hline \multirow{2}{*}{ Perlakuan } & \multicolumn{5}{c}{ Kandungan zat makanan periode starter } \\
\cline { 2 - 5 } & PK & SK & ME & LK \\
\hline P0 & 23.26 & 4.11 & 3229.13 & 3.908 \\
P1 & 22.856 & 4.528 & 3212.63 & 3.880 \\
P2 & 22.452 & 4.946 & 3196.12 & 3.852 \\
P3 & 22.048 & 5.364 & 3179.62 & 3.824 \\
\hline \multirow{2}{*}{ Perlakuan } & PK & Kandungan zat makanan periode finisher \\
P0 & 20.185 & SK & ME & LK \\
P1 & 19.781 & 4.6675 & 3223.55 & 4.468 \\
P2 & 19.377 & 5.0835 & 3207.05 & 4.350 \\
P3 & 18.973 & 5.5015 & 3190.55 & 4.322 \\
\hline
\end{tabular}

perlakuan penambahan tepung kunyit (K0 $=0 \%$ dan $\mathrm{K} 1=2,5 \%$ dari total pakan), dan perlakuan vaksin $(\mathrm{V} 0=$ tidak divaksin dan $\mathrm{V} 1$ = divaksin).

Ayam dipelihara selama 5 minggu dan diberi pakan serta minum secara ad libitum. Pakan yang diberikan dibedakan untuk ayam umur 0-3 minggu (periode starter) dan untuk ayam umur 4-5 minggu (periode finisher). Perlakuan vaksin (V1) diberikan pada ayam umur 4 hari dengan cara tetes mata dan umur 4 minggu dengan melalui air minum yaitu memakai vaksin ND. Konsumsi pakan dan air minum dicatat setiap hari yang ditotal tiap minggu, sedangkan penimbangan $\mathrm{BB}$ dilakukan setiap minggu sampai minggu kelima pemeliharaan. 


\section{Peubah yang diamati}

Peubah yang diamati pada ayam pedaging adalah sebagai berikut:

1. Konsumsi pakan (g/ekor), diukur berdasarkan jumlah pakan yang diberikan (g) setiap hari dikurangi dengan sisa pakan (g) setiap hari selama satu minggu, Pengukuran ini selama penelitian berlangsung (Rusdi, 1992);

2. Konsumsi air minum(ml/ekor/minggu), diukur setiap hari untuk satu minggu berdasarkan jumlah air minum yang diberikan (ml) setiap hari selama satu minggu dikurangi dengan sisa air minum (ml) setiap hari selama satu minggu, selama penelitian berlangsung (Rasyaf, 2004);

3. Pertambahan bobot badan (g), diukur berdasarkan selisih antara BB akhir (g) dan BB awal (g) pada setiap unit percobaan pada setiap minggu selama 6 minggu (Soeharsono, 1976);

4. Konversi pakan, dihitung berdasarkan jumlah pakan yang dikonsumsi (g) dibagi dengan PBB (g) setiap minggu selama penelitian berlangsung (Rusdi, 1992);

5. Nilai ekonomis pakan (income over feed and chick cost = IOFCC), dihitung berdasarkan selisih antara jumlah penerimaan rata-rata dari hasil penjualan ayam $(\mathrm{Rp})$ dan jumlah biaya pengeluaran untuk pakan (Rp) dan DOC (Rasyaf, 1993);

Semua data hasil penelitian dianalisis ragam menggunakan RAL pola faktorial $4 \times 2 \times 2$ Karena tidak terdapat interaksi, maka pengujian dilakukan terhadap pengaruh utama (main effect) dari masing-masing faktor (Steel dan Torrie, 1980). Uji lanjut terhadap pengaruh sederhana atau utama dilakukan dengan metode Duncan's Multiple Range Test (DMRT) sesuai dengan petunjuk Steel dan Torrie (1980).

HASIL DAN PEMBAHASAN

Pengaruh Level Produk Fermentasi dan kunyit dalam Pakan, Pemberian Vaksin serta Interaksi Ketiga Faktor Tersebut terhadap Konsumsi Pakan Ayam Pedaging

Konsumsi pakan kumulatif adalah jumlah pakan yang dikonsumsi setiap ekor ayam selama 5 minggu penelitian. Data konsumsi pakan per ekor selama 5 minggu penelitian disajikan pada Tabel 3 .

Pada Tabel 3 tampak bahwa konsumsi pakan kumulatif tertinggi adalah kombinasi perlakuan P1K0V1 (level 10\% produk fermentasi, tanpa kunyit, dan diberi vaksin) yaitu 2.686,51 g, sedangkan terendah adalah P1K1V1 yaitu 2.268,96. Hasil analisis ragam menunjukkan 
Tabel 3. Pengaruh tingkat penggunaan produk fermentsi dan kunyit dalam pakan, pemberian vaksin serta interaksi ketiga faktor tersebut terhadap konsumsi pakan (g)

\begin{tabular}{cccccccc}
\hline \multirow{2}{*}{ Kunyit* } & \multirow{2}{*}{ Vaksin* } & \multicolumn{4}{c}{ Level produk fermentasi** } & Ratan & Rataan \\
\cline { 3 - 6 } & & P0 & P1 & P2 & P3 & kunyit & Vaksin \\
\hline \multirow{2}{*}{ K1 } & V1 & $2,560.33$ & $2,268.96$ & $2,538.47$ & $2,637.96$ & $2,492.61$ & $2,571.49$ \\
& V0 & $2,353.23$ & $2,686.25$ & $2,547.82$ & $2,347.90$ & & $2,505.00$ \\
K0 & V1 & $2,665.67$ & $2,686.51$ & $2,655.48$ & $2,558.56$ & $2,583.88$ & \\
& V0 & $2,572.47$ & $2,472.38$ & $2,656.01$ & $2,403.96$ & & \\
& & $2,537.92$ & $2,528.52$ & $2,599.44$ & $2,481.26$ & & \\
\hline
\end{tabular}

Keterangan: *kunyit/vaksin 1 dan 0 masing-masing adalah diberi dan tanpa kunyit/vaksin**level produk fermentasi P0, P1, P2, dan P3 adalah masingmasing tanpa produk fermentasi, ditambah 10, 20, dan $30 \%$ produk fermentasi dalam pakan

bahwa tidak ada interaksi antara level produk fermentasi, pemberian kunyit, dan pemberian vaksin terhadap konsumsi pakan. Hasil penelitian juga menunjukkan bahwa masing-masing faktor tidak berpengaruh nyata $(\mathrm{P}>0,05)$ terhadap konsumsi pakan.

\section{Pengaruh Level Produk Fermentasi dan Kunyit dalam Pakan, Pemberian Vaksin serta Interaksi Ketiga Faktor Tersebut terhadap Konsumsi Minum}

Konsumsi air minum kumulatif adalah jumlah air minum yang diminum setiap ekor ayam selama 5 minggu penelitian. Data konsumsi air minum per ekor selama 5 minggu penelitian disajikan pada Tabel 4. Pada Tabel 4 tampak bahwa konsumsi air minum kumulatif tertinggi adalah kombinasi perlakuan P0K1V1 (5.760,73 ml), sedangkan terendah adalah P2K1V0 yaitu 4.924,58 $\mathrm{ml}$.

Tabel 4. pengaruh tingkat penggunaan produk fermentsi dan kunyit dalam pakan, pemberian vaksin serta interaksi ketiga faktor tersebut terhadap konsumsi air minum (ml)

\begin{tabular}{cccccccc}
\hline \multirow{2}{*}{ Kunyit } & \multirow{2}{*}{ Vaksin } & \multicolumn{4}{c}{ Level produk fermentasi } & Ratan & Rataan \\
\cline { 3 - 6 } & & P0 & P1 & P2 & P3 & kunyit & Vaksin \\
\hline \multirow{2}{*}{ K1 } & V1 & $5,760.73$ & $5,112.00$ & $5,552.78$ & $5,609.00$ & $5,440.49$ & $5,630.65$ \\
& V0 & $5,506.07$ & $5,609.38$ & $4,924.58$ & $5,449.36$ & & $5,467.86$ \\
K0 & V1 & $6,116.17$ & $5,600.77$ & $5,835.64$ & $5,458.13$ & $5,658.02$ & \\
& V0 & $5,558.91$ & $5,624.42$ & $5,447.84$ & $5,622.32$ & & \\
& & $5,735.47$ & $5,486.64$ & $5,440.21$ & $5,540.23$ & & \\
\hline
\end{tabular}

Keterangan: *kunyit/vaksin 1 dan 0 masing-masing adalah diberi dan tanpa kunyit/vaksin **level produk fermentasi P0, P1, P2, dan P3 adalah masing-masing tanpa produk fermentasi, ditambah 10,20 , dan $30 \%$ produk fermentasi dalam pakan 
Hasil analisis ragam menunjukkan bahwa tidak ada interaksi antara level produk fermentasi, pemberian kunyit, dan pemberian vaksin terhadap konsumsi air minum. Hasil penelitian juga menunjukkan bahwa masing-masing faktor tidak berpengaruh nyata $(\mathrm{P}>0,05)$ terhadap konsumsi air minum.

\section{Pengaruh Level Produk Fermentasi dan Kunyit dalam Pakan, Pemberian Vaksin serta Interaksi Ketiga Faktor Tersebut terhadap Pertambahan Bobot Badan Ayam Pedaging}

Pertambahan bobot badan merupakan manifestasi dari pertumbuhan yang dicapai selama penelitian, yakni bobot akhir dikurangi bobot awal atau bobot DOC. Data pertambahan bobot badan per ekor selama 5 minggu penelitian disajikan pada Tabel 5. Pada Tabel 5 tampak bahwa pertambahan bobot badan ayam pedaging tertinggi pada kombinasi perlakuan P1K1V1 $(1.764,81$ g) dan terendah pada kombinasi perlakuan P3K1V0 (1.242,42 g). Hasil analisis ragam menunjukkan bahwa tidak ada interaksi antara level produk fermentasi dan kunyit, dan pemberian vaksin terhadap pertambahan bobot badan. Hasil penelitian juga menunjukkan level produk fermentasi dalam pakan mempengaruhi pertambahan bobot badan $(\mathrm{P}<0.05)$. Bobot badan pada perlakuan P1 dan P0 tidak berbeda nyata $(\mathrm{P}>0.05)$, namun keduanya lebih tinggi $(\mathrm{P}<0.05)$ dari perlakuan $\mathrm{P} 2$ dan $\mathrm{P} 3$. Perlakuan P2 dan P3 tidak berbeda nyata $(\mathrm{P}>0,05)$. Bobot badan hasil penelitian ini lebih tinggi dan lebih cepat dicapai pada umur 5 minggu dibandingkan dengan hasil penelitian Nurhayati (2007) dengan

Tabel 5. Pengaruh tingkat penggunaan produk fermentsi dan kunyit dalam pakan, pemberian vaksin serta interaksi ketiga faktor tersebut terhadap pertambahan bobot badan (g)

\begin{tabular}{|c|c|c|c|c|c|c|c|}
\hline \multirow{2}{*}{ Kunyit* } & \multirow{2}{*}{ Vaksin* } & \multicolumn{4}{|c|}{ Level produk fermentasi** } & \multirow{2}{*}{$\begin{array}{l}\text { Ratan } \\
\text { kunyit }\end{array}$} & \multirow{2}{*}{$\begin{array}{l}\text { Rataan } \\
\text { Vaksin }\end{array}$} \\
\hline & & P0 & $\mathrm{P} 1$ & P2 & P3 & & \\
\hline \multirow[t]{2}{*}{ K1 } & V1 & $1,575.25$ & $1,764.81$ & $1,356.60$ & $1,283.20$ & $1,447.70$ & $1,507.24$ \\
\hline & V0 & $1,482.28$ & $1,588.34$ & $1,288.74$ & $1,242.42$ & & $1,439.67$ \\
\hline \multirow[t]{3}{*}{ K0 } & V1 & $1,630.15$ & $1,575.89$ & $1,476.80$ & $1,395.19$ & $1,499.20$ & \\
\hline & V0 & $1,558.55$ & $1,612.54$ & $1,415.84$ & $1,328.69$ & & \\
\hline & & $1,561.56 b$ & $1,635.39 b$ & $1,384.49 \mathrm{a}$ & $1,361.94 \mathrm{a}$ & & \\
\hline
\end{tabular}

Keterangan: *kunyit/vaksin 1 dan 0 masing-masing adalah diberi dan tanpa kunyit/vaksin **level produk fermentasi $0,1,2$, dan 3 adalah masing-masing tanpa produk fermentasi, ditambah 10, 20, dan 30\% produk fermentasi dalam pakan Huruf yang berbeda pada baris yang sama menunjukkan perbedaan yang nyata $(\mathrm{P}<0.05)$ 
perlakuan penambahan bahan fermentasi $0, \quad 10,20$, dan $30 \%$ dalam pakan menghasilkan pertambahan bobot badan masing-masing $1.219 \mathrm{~g}, \quad 1.428,22 \mathrm{~g}$, $1.468,41 \mathrm{~g}$, dan $1.405,82 \mathrm{~g}$ yang dicapai pada umur 6 minggu. Pakan yang mengandung produk fermentasi sampai batas $10 \%$ cenderung menaikkan pertambahan bobot badan ayam, diatas $10 \%$ cenderung menurunkan PBB.

Penurunan PBB tersebut disebabkan oleh semakin meningkatnya kandungan SK dalam ransum yang sejalan dengan meningkatnya level penggunaan bahan fermentasi. Ransum unggas yang mengandung SK dalam jumlah yang tinggi dapat mengakibatkan pakan sulit dicerna sehingga dapat mengganggu kecernaan zat makanan dan dapat keluar bersama feses. Akibatnya zat makanan tersebut tidak dapat dimanfaatkan untuk pertumbuhan ternak.

\section{Pengaruh Level Produk Fermentasi dan Kunyit dalam Pakan, Pemberian Vaksin serta Interaksi Ketiga Faktor Tersebut terhadap Konversi Pakan}

Konversi pakan didefinisikan sebagai jumlah pakan yang dikonsumsi dibagi pertambahan bobot badan. Konversi ransum merupakan indikator baik tidaknya pakan yang diberikan pada ayam broiler, semakin besar nilai konversi pakan semakin besar kebutuhan pakan yang diperlukan untuk setiap satuan bobot badan atau semakin besar biaya produksi atau semakin tidak efisien penggunaan pakan tersebut. Data konversi pakan hasil penelitian disajikan pada Tabel 6. Pada Tabel 6 tampak bahwa konversi pakan terbaik (terkecil) adalah pada kombinasi perlakuan P1K1V1 $(1,3)$, sedangkan yang tertinggi adalah kombinasi perlakuan P3K1V1 $(2,06)$.

Tabel 6. Pengaruh tingkat penggunaan produk fermentsi dan kunyit dalam pakan, pemberian vaksin serta interaksi ketiga faktor tersebut terhadap konversi pakan

\begin{tabular}{|c|c|c|c|c|c|c|c|}
\hline \multirow{2}{*}{ Kunyit* } & \multirow{2}{*}{ Vaksin* } & \multicolumn{4}{|c|}{ Level produk fermentasi** } & \multirow{2}{*}{$\begin{array}{l}\text { Ratan } \\
\text { kunyit }\end{array}$} & \multirow{2}{*}{$\begin{array}{l}\text { Rataan } \\
\text { Vaksin }\end{array}$} \\
\hline & & P0 & P1 & $\mathrm{P} 2$ & P3 & & \\
\hline \multirow[t]{2}{*}{ K1 } & V1 & 1.63 & 1.30 & 1.87 & 2.06 & \multirow[t]{2}{*}{1.75} & 1.73 \\
\hline & V0 & 1.59 & 1.70 & 1.98 & 1.90 & & 1.76 \\
\hline \multirow[t]{3}{*}{ K0 } & V1 & 1.64 & 1.72 & 1.80 & 1.84 & \multirow[t]{3}{*}{1.74} & \\
\hline & V0 & 1.65 & 1.54 & 1.88 & 1.82 & & \\
\hline & & $1.63^{\mathrm{a}}$ & $1.56^{\mathrm{a}}$ & $1.88^{\mathrm{b}}$ & $1.83^{\mathrm{b}}$ & & \\
\hline
\end{tabular}

Keterangan: *kunyit/vaksin 1 dan 0 masing-masing adalah diberi dan tanpa kunyit/vaksin **level produk fermentasi P0, P1, P2, dan P3 adalah masing-masing tanpa produk fermentasi, ditambah 10, 20, dan $30 \%$ produk fermentasi dalam pakan Superskript dengan huruf yang berbeda pada baris yang sama menunjukkan perbedaan yang nyata $(\mathrm{P}<0.05)$ 
Hasil analisis ragam menunjukkan bahwa tidak ada interaksi antara level produk fermentasi dan kunyit dalam pakan, dan pemberian vaksin terhadap konversi pakan. Hasil penelitian juga menunjukkan bahwa konversi pakan pada perlakuan P1 dan P0 tidak berbeda nyata $(\mathrm{P}>0.05)$, namun keduanya nyata lebih rendah $(\mathrm{P}<0.05)$ dibanding dari perlakuan P2 dan P3. Perlakuan P2 dan P3 tidak berbeda nyata $(\mathrm{P}>0,05)$. Rendahnya konversi pakan pada P2 dan P3 diduga dipengaruhi oleh kandungan SK yang tinggi dalam pakan. Kandungan SK yang tinggi ini dapat mengakibatkan sebagian energi pakan terbuang untuk mencerna SK sehingga pemanfaatan zat makanan menjadi daging semakin berkurang atau tidak efisien.Konversi pakan pada penelitian ini lebih rendah atau lebih baik dari hasil penelitian Nurhayati (2007) dimana ayam pedaging yang mendapat pakan fermentasi $0,10,20$, dan 30\% dalam pakan, konversi ransumnya berturut-turut adalah 2,45, 2,22, 2,34, dan 2,57.

\section{Pengaruh Level Produk Fermentasi dan Kunyit dalam Pakan, Pemberian Vaksin serta Interaksi Ketiga Faktor Tersebut terhadap Income Over Feed and Chick Cost (IOFCC)}

\section{Income Over Feed and Chick}

Cost merupakan indikator nilai ekonomis dari pakan dan DOC yang diberikan pada ayam pedaging. Income Over Feed and Chick Cost adalah besarnya keuntungan kotor yang diperoleh dari hasil penjualan bobot hidup seekor ayam pedaging dikurangi biaya pakan yang dikonsumsi dan biaya pembelian DOC. Data IOFCC hasil penelitian disajikan pada Tabel 7 .

Tabel 7. pengaruh level produk fermentsi dan kunyit dalam pakan, pemberian vaksin serta interaksi ketiga faktor tersebut terhadap IOFCC (Rp)

\begin{tabular}{|c|c|c|c|c|c|c|c|}
\hline \multirow{2}{*}{ Kunyit* } & \multirow{2}{*}{ Vaksin* } & \multicolumn{4}{|c|}{ Level produk fermentasi** } & \multirow{2}{*}{$\begin{array}{l}\text { Ratan } \\
\text { kunyit }\end{array}$} & \multirow{2}{*}{$\begin{array}{l}\text { Rataan } \\
\text { Vaksin }\end{array}$} \\
\hline & & $\mathrm{P} 0$ & P1 & $\mathrm{P} 2$ & P3 & & \\
\hline \multirow[t]{2}{*}{ K1 } & V1 & $9,826.10$ & $12,571.22$ & $8,143.10$ & $7,732.70$ & $9,001.14$ & $9,715.52$ \\
\hline & V0 & $8,710.46$ & $10,453.52$ & $7,328.72$ & $7,243.28$ & & $8,904.76$ \\
\hline \multirow[t]{3}{*}{ K0 } & V1 & $10,484.90$ & $10,304.12$ & $9,585.50$ & $9,076.52$ & $9,619.14$ & \\
\hline & V0 & $9,625.70$ & $10,743.92$ & $8,853.92$ & $8,278.52$ & & \\
\hline & & $9,661.79^{b}$ & $11,018.20^{c}$ & $8,477.81^{\mathrm{a}}$ & $8,677.52^{\mathrm{a}}$ & & \\
\hline
\end{tabular}

Keterangan: *kunyit/vaksin 1 dan 0 masing-masing adalah diberi dan tanpa kunyit/vaksin **level produk fermentasi P0, P1, P2, dan P3 adalah masing-masing tanpa produk fermentasi, ditambah 10,20 , dan $30 \%$ produk fermentasi dalam pakan Superskript dengan huruf yang berbeda pada baris yang sama menunjukkan perbedaan yang sangat nyata $(\mathrm{P}<0.05)$ 
Pada Tabel 7 tampak bahwa rerata Income Over Feed and Chick Cost (IOFCC) yang tertinggi adalah kombinasi perlakuan P1K1V1 (Rp12.571,22) dan terendah adalah perlakuan P3K1V0 (Rp7.243,28). Hasil analisis ragam menunjukkan bahwa tidak ada interaksi antara level produk fermentasi dan kunyit dalam pakan, dan pemberian vaksin terhadap Income Over Feed and Chick Cost. Hasil penelitian menunjukkan bahwa level produk fermentasi dalam pakan mempengaruhi IOFCC $(\mathrm{P}<0.01)$ Hasil penelitian menunjukkan bahwa P2 dan P3 tidak berbeda nyata $(\mathrm{P}>0.05)$, tetapi keduanya lebih rendah $(\mathrm{P}<0.05)$ daripada $\mathrm{P} 1$ dan $\mathrm{P} 0$, sedangkan perlakuan P1 lebih tinggi $(\mathrm{P}<0.05)$ dari $\mathrm{P} 0$.

IOFCC pada penelitian ini lebih tinggi dari hasil penelitian Nurhayati (2007) dengan perlakuan penambahan bahan fermentasi sebanyak $0,10,20$, dan $30 \%$ dalam pakan ayam pedaging (umur 6 minggu) yang menghasilkan IOFCC masing-masing Rp 2.889,93, Rp 4.678,53, Rp 4804,49, dan Rp 4024,04. Lebih tingginya IOFCC pada penelitian ini disebabkan lebih tingginya PBB dan lebih cepat pertumbuhannya sehingga bobot badan akhir lebih tinggi dan dicapai pada umur yang lebih muda (5 minggu).

\section{KESIMPULAN DAN SARAN}

Berdasarkan hasil penelitian dan pembahasan di atas dapat disimpulkan beberapa hal sebagai berikut:

1. Tidak ada interaksi antara tingkat penggunaan produk fermentasi, penambahan kunyit, dan perlakuan vaksin terhadap performan ayam pedaging.

2. Penambahan produk fermentasi sebanyak $10 \%$ dalam pakan ayam pedaging dapat meningkatkan performan ayam pedaging (dengan PBB paling tinggi dan konversi pakan paling baik).

3. Penambahan produk fermentasi $10 \%$ dan penambahan kunyit $2,5 \%$ dalam pakan dapat menghasilkan IOFCC yang lebih tinggi dibandingkan dengan kontrol.

4. Penambahan produk fermentasi, penambahan kunyit dalam pakan dan perlakuan pemberian Vaksin tidak mempengaruhi konsumsi pakan dan konsumsi minum.

\section{Saran:}

Penambahan kunyit dalam pakan perlu ditingkatkan dengan dosis yang lebih tinggi supaya bersinergi dengan produk fermentasi dalam peningkatan performan ayam pedaging dan IOFCC. 


\section{DAFTAR PUSTAKA}

Nova, K. 2001. Kajian Penggunaan Tepung Kunyit (Curcuma domestica) dalam Ransum Ayam Pedaging. Jurnal Peternakan dan Lingkungan 7(3):20-25.

Nurhayati, O. Sjofjan, dan Koentjoko. 2006. Kualitas Nutrisi Campuran Bungkil Inti Sawit dan Onggok yang Difermentasi Menggunakan Aspergillus niger. Jurnal Pengembangan Peternakan Tropis vol.31, No.3: 172-178.

Nurhayati. 2007. Pengaruh Tingkat Penggunaan Campuran Bungkil Inti Sawit dan Onggok Terfermentasi oleh Aspergillus niger dalam Pakan terhadap Penampilan Ayam Pedaging. Jurnal Pengembangan Peternakan Tropis vol.32, No.1: 28-32.

Nurhayati, C.U. Wirawati, D.D. Putri. 2011. Kajian Fermentasi Campuran Bungkil Inti Sawit dan Onggok dengan Lama Fermentasi dan Level Penambahan Mineral Berbeda. Prosiding Seminar Nasional Sains dan Teknologi IV, Bandar Lampung, 29-30 November 2011. Lembaga Penelitian Universitas Lampung.

Rasyaf, M. 1993. Beternak Ayam Pedaging. Penebar Swadaya. Jakarta.

Rasyaf, M. 2004. Beternak Ayam Petelur. Penebar Swadaya. Jakarta.
Retnaningati dan Tutik. 2006. Potensi Tepung Jahe, Kunyit, dan Temulawak sebagai Pakan Tambahan terhadap Konsumsi Pakan, Pertambahan Berat Badan dan Konversi Pakan Ayam Pedaging Jantan. Skripsi. Fakultas Kedokteran Hewan. Universitas Airlangga. Surabaya.

Rusdi, U.D. 1992. Fermentasi Konsentrat Campuran Bungkil Biji Kapok dan Onggok serta Implikasi Efeknya terhadap Pertumbuhan Ayam Broiler. Disertasi. Universitas Padjadjaran. Bandung.

Soeharsono. 1976. Respon Broiler terhadap berbagai Kondisi Lingkungan. Disertasi. Universitas Padjadjaran. Bandung.

Steel, R.G.D. and J.H. Torrie. 1980. Principles and Procedures of Statistics, A Biometrical Approach. International Student Ed. McGrawHill. Kogakusha Limited, Tokyo.

Tantalo, S. 2006. Pengaruh Penggunaan Kunyit dan Jenis Ransum Komersial terhadap Performans Broiler. Laporan Penelitian. Fakultas Pertanian Unila. Bandar Lampung. 